\title{
In vitro Apatite Formation, Protein Adsorption and Initial Osteoblast Responses on Titanium Surface Enriched with Magnesium
}

\author{
Xu Lingli, Shi Xingling, Ouyang Chun, Liu Wen
}

Jiangsu University of Science and Technology, Zhenjiang 212003, China

\begin{abstract}
A feasible treatment to modify titanium with $\mathrm{Mg}$ was carried out. Briefly, pure titanium was treated in condensed sodium hydroxide solution first and then transferred to diluted magnesium chloride solution to conduct ion exchange. After that, heat treatment was conducted and a nano-sized network containing magnesium titanate was obtained. Surface morphology, roughness, and chemical composition were characterized. In vitro apatite inducing ability was evaluated in simulated body fluid (SBF) and bovine serum albumin (BSA) was used as model to study protein adsorption. MC3T3-E1 cells were cultured and initial cell attachment, morphology, proliferation were evaluated. Results show that compared with sodium (Na) modified surface, $\mathrm{Mg}$ immobilization accelerates apatite formation and promotes protein adsorption significantly. Besides, cell attachment is improved and cell spreading is enhanced on $\mathrm{Mg}$-containing samples compared with $\mathrm{Na}$ containing samples. Increased early cellular attachment results in subsequent increase of number of proliferated cells on the Mg-containing surface.
\end{abstract}

Key words: titanium; osteoconductivity; magnesium; apatite; protein; osteoblast

Pure titanium and its alloys are widely used as bone substitute in dentistry and orthopedics due to their good corrosion resistance and proper mechanical strength matching with bone ${ }^{[1,2]}$. However, as titanium is bioinert material it cannot bond directly to living bone and fibrous capsule always formed isolating the implant from surrounding bone ${ }^{[3]}$. Initial osseointegration is considered to be crucial for long-term implantation success, and thus surface modification of medical titanium and its alloys for rapid and firm osseointegration has been research interest since they were used as load-bearing bone substitute.

Protein adsorption is the most immediate event after implantation and is critical for the biocompatibility of all implant materials. Cell adhesion and subsequent proliferation, differentiation are mediated by interactions between cell integrins and adsorbed proteins and thus the amount and type of protein absorbed onto implants surface consequently affect the behaviors of osteoblasts ${ }^{[4,5]}$. Magnesium $(\mathrm{Mg})$ is the fourth most abundant mineral in human body and $\mathrm{Mg}$ ions are known to enhance adhesion of osteoblast via ligand binding of the integrin receptors ${ }^{[6]}$. In order to improve protein adsorption, titanium implants surface are modified with $\mathrm{Mg}$ through various techniques, including electrochemical oxidation, hydrothermal treatment and ion implantation $^{[7-12]}$.

For implants with complex shapes, hydrothermal treatment and electrochemical oxidation are preferred since uniform bioactive oxidation layer with certain cations can be formed all over the titanium surface. The amount of interesting element immobilized onto titanium was limited by hydrothermal method[13,14]. Increasing the pH of hydrothermal medium will benefit incorporation of cations; however, it also causes the precipitation of hydroxide of alkaline element, such $\mathrm{Mg}(\mathrm{OH})_{2}$, which will depress cell responses ${ }^{[15,16]}$. Besides, hydrothermal treatment and electrochemical oxidation need complex devices to supply de-

Received date: May 17, 2016

Foundation item: Priority Academic Program Development of Jiangsu Higher Education Institutions; Doctor Project of Jiangsu University of Science and Technology $(635061402)$

Corresponding author: Shi Xingling, Ph. D., School of Material Science and Engineering, Jiangsu University of Science and Technology, Zhenjiang 212003, P. R. China, Tel: 0086-511-84401184, E-mail: shixingling1985@ hotmail.com 
fined electric filed or to guarantee reaction at high pressure under temperature as high as $200^{\circ} \mathrm{C}$.

It was concluded that the formation of titania gel would benefit the adsorption divalent cations that show much stronger affinity towards titania compared with univalent ones[17]. Thus, it is possible to replace the Na combined into titanium surface during alkaline treatment with a large amount of other bioactive elements such as zinc ( $\mathrm{Zn})$, calcium $(\mathrm{Ca})$ and $\mathrm{Mg}$. In the present work we prepared titanium specimens enriching in $\mathrm{Mg}$ by an alkaline-immersion-heat treatment method and the effects of $\mathrm{Mg}$ cations on apatite formation, protein adsorption and cell responses were evaluated in comparison with $\mathrm{Na}$ enriched specimens.

\section{Experiment}

Commercially pure titanium disks (Kobe Steel Ltd, Japan), $\Phi 15 \mathrm{~mm} \times 1.0 \mathrm{~mm}$, were used in the experiments. Samples were wet-abraded with 400 -grit $\mathrm{SiC}$ abrasive paper and then ultrasonically washed in acetone and distilled water for $30 \mathrm{~min}$. After dried in hot air, Ti samples were immersed in $5.0 \mathrm{~mol} / \mathrm{L} \mathrm{NaOH}$ solution at $60{ }^{\circ} \mathrm{C}$ for $24 \mathrm{~h}$ and then were washed by distilled water thoroughly. Alkaline-treated samples were either dried in hot air or immersed into $0.1 \mathrm{~mol} / \mathrm{L} \mathrm{MgCl}_{2}$ at $60{ }^{\circ} \mathrm{C}$ for another $24 \mathrm{~h}$. Finally, further immersed samples were rinsed by distilled water and dried in hot air. After chemical treatment, samples were placed into a muffle furnace and subjected to a heat treatment at $600{ }^{\circ} \mathrm{C}$ in air for $1 \mathrm{~h}$. The temperature rising speed was $5^{\circ} \mathrm{C} / \mathrm{min}$. Samples were coded with regard to the cations, namely, $\mathrm{NaTi}$ for $\mathrm{NaOH}$-heat treated and $\mathrm{MgTi}$ for $\mathrm{NaOH}-\mathrm{MgCl}_{2}$-heat treated. Untreated titanium discs were coded as UnTi.

\subsection{Surface characterizations}

Surface morphologies of the samples were observed with scanning electronic microscope (SEM, S-3000, Hitachi Co., Japan). Surface roughnesses of samples were analyzed by color 3D laser scanning microscope (VK9710, Keyence Co., Japan).The surface chemical compositions of samples were detected by X-ray photoelectron spectroscopy (XPS, K-alpha, Thermo Fisher Scientific, UK). Crystalline structures in the top layer of samples were investigated by grazing incidence X-ray diffraction (GIXRD, D8 Advance, Bruker AXS Inc., USA). The diffraction data were recorded at an X-ray incidence angle of $4^{\circ}$.

\subsection{In vitro apatite induction}

Samples were put into individual PE bottles containing $35 \mathrm{~mL}$ simulated body fluid (SBF) and were kept in an incubator set at $36.5^{\circ} \mathrm{C}$ as proposed by Kokubo et al ${ }^{[18]}$. After $2 \mathrm{~d}$ of incubation, samples were taken out, rinsed gently with distilled water and then dried in hot air at $60^{\circ} \mathrm{C}$. The surfaces of samples after immersed in SBF were characterized by SEM.

\subsection{Protein adsorption}

Bovine serum albumin, fraction V (BSA, Pierce Biotechnology Inc., Rockford, IL) was used as a model protein and Bradford method was employed. $200 \mu$ of protein solution (1 $\mathrm{mg}$ of protein in per $\mathrm{mL}$ of saline) was spread over Ti disks lying on the bottom of 12-well cell culture plate using a pipette. The adsorption was then conducted in a sterile humidified incubator at $37^{\circ} \mathrm{C}$ for $3 \mathrm{~h}$. After incubation, 100 $\mu \mathrm{L}$ of protein solution from top of each sample was mixed with $5.0 \mathrm{~mL} 5$-times diluted assay solution. $200 \mu \mathrm{L}$ of the mixture from each sample was pipetted into a well of 48-well plate and 3 replicates for each sample were used. The samples were incubated at room temperature for $5 \mathrm{~min}$ and absorbance was read at $595 \mathrm{~nm}$ using an auto microplate reader (Infinite M200, Tecan, Austria). Calibration curve was prepared by measuring diluted series of standard solution.

\subsection{Cell culture}

MC3T3-E1 cells, a mouse calvaria-derived osteoblast-like cell line, were cultured in L-glutamine containing alpha-Minimum Essential Media ( $\alpha$-MEM, GIBCO/Invitrogen, Grand Island, NY, USA) supplemented with $10 \%$ fetal bovine serum (FBS, Invitrogen, Carlsbad, CA, USA), $1 \%$ penicillin (10000 units) and streptomycin $(10 \mathrm{mg} / \mathrm{mL})$. The cells were cultured under $100 \%$ humidity and $5 \% \mathrm{CO}_{2}$ at $37^{\circ} \mathrm{C}$. The medium was changed every other day and cells were passaged using $0.05 \%$ trypsin/0.02\% EDTA (Invitrogen, Carlsbad, CA, USA) prior to confluenced.

\subsection{Initial cell attachment and proliferation}

Cells were seeded onto Ti samples in 24-well plate at an initial density of $4 \times 10^{4}$ cells/well. After cultured for $3 \mathrm{~h}$ and $24 \mathrm{~h}$ cells were washed with phosphate buffer saline (PBS) and trypsinized. The attached cells were then counted by hemocytometer.

After $3 \mathrm{~h}$ of culture, cells attached to the disks were fixed with $3 \%$ glutaraldehyde, post fixed with $1 \% \mathrm{OsO}_{4}$ solution and then dehydrated using a series of ethanol solution with graded concentration. Subsequently, they were dried with the $t$-butyl alcohol freeze-drying method and sputtered with Au-Pt alloy coating for SEM observation.

For proliferation, cells were seeded on disks in 24-well plates at $1 \times 10^{4}$ cells/well and Alamar Blue assay (Biosource International, Camarillo, CA) was performed after cultured for $1,3,5$ and $7 \mathrm{~d}$. At each time point, the medium was replace by $1.0 \mathrm{~mL}$ culture medium with $10 \%$ Alamar Blue reagent and the cells were further incubated for $3 \mathrm{~h} .100 \mu \mathrm{L}$ ( 3 replicates for each sample) of the medium from each well was transferred to a 96 -well plate and the fluorescence $\left(\lambda_{\mathrm{ex}}=560 \mathrm{~nm}, \lambda_{\mathrm{em}}=590 \mathrm{~nm}\right)$ was read. The remaining Alamar Blue in well-plate was washed away with $\alpha$-MEM and fresh culture medium was added for further incubation.

\subsection{Statistical analysis}


Statistical analysis was performed by one-way analysis of variance (ANOVA) using Origin 8.5 (OriginLab, Co., USA). Scheffe's test was used for individual comparisons of groups and $p<0.05$ was considered to be statistically different.

\section{Results and Discussion}

\subsection{Surface characterizations}

Fig.1 shows the surface morphologies of different samples. It can be seen that after chemical and subsequent heat treatment a fine 3D structured network is formed. The network structures on two kinds of samples are definitely similar to each other. Surface roughness $\left(R_{\mathrm{a}}\right)$ of NaTi and MgTi are $0.42 \pm 0.01$ and $0.43 \pm 0.01 \mu \mathrm{m}$, respectively.

XPS analysis results of each sample are presented in Table 1. After alkaline treatment about 10.3 at\% of $\mathrm{Na}$ is combined into titanium surface. However, after further immersion treatment, $\mathrm{Na}$ is completely removed or replaced by $\mathrm{Mg}$, as shown in Fig.2, and Na1s cannot be detected on samples any more. The atom percentage of $\mathrm{Mg}$ combined into titanium surface is 3.1 at $\%$

Fig. 3 shows the XRD patterns of different samples. On NaTi surface sodium titanate and rutile are found. Diffraction peaks are ascribed to anatase, magnesium titanate and rutile are detected on MgTi surface.

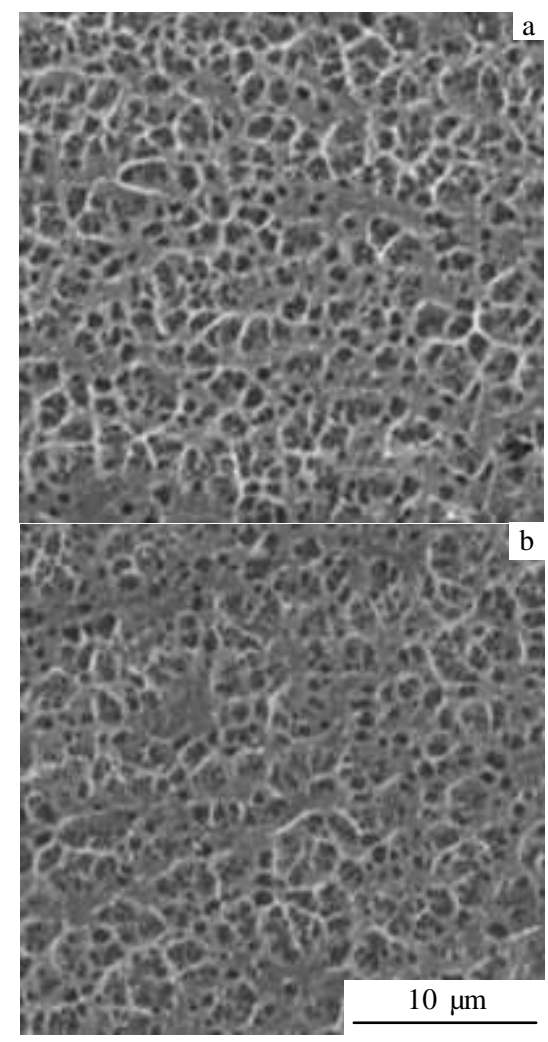

Fig.1 SEM images of NaTi (a) and MgTi (b) surfaces
Table 1 Chemical composition of different specimens (at\%)

\begin{tabular}{cccccc}
\hline Sample & $\mathrm{Ti}$ & $\mathrm{O}$ & $\mathrm{C}$ & $\mathrm{Na}$ & $\mathrm{Mg}$ \\
\hline UnTi & 20.39 & 40.62 & 35.39 & - & - \\
$\mathrm{NaTi}$ & 20.43 & 49.15 & 20.13 & 10.29 & - \\
$\mathrm{MgTi}$ & 20.06 & 50.97 & 25.9 & - & 3.07 \\
\hline
\end{tabular}

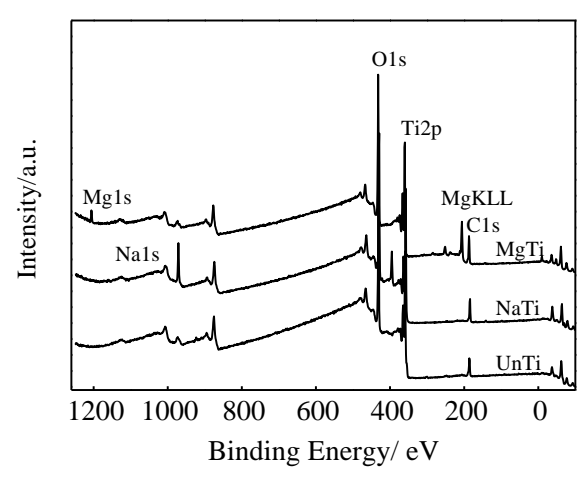

Fig.2 XPS survey scans of different specimens

During the alkaline treatment, $\mathrm{TiO}_{2}$ layer on metal titanium partially dissolved due to the attack of $\mathrm{OH}^{-}$groups to form negatively charged $\mathrm{HTiO}^{3-}$ groups. Simultaneously, titanium would be hydrated and precipitated to supply $\mathrm{TiO}_{2}$. Negatively charged groups would combine with $\mathrm{Na}$ ions to form a titanate hydrogel layer. During heat treatment, the hydrogel layer is dehydrated and constructed into stable sodium titanate layer.

According to $\mathrm{pNa}-\mathrm{pH}$ diagram of the $\mathrm{Na}-\mathrm{Ti}-\mathrm{H}_{2} \mathrm{O}$ system, sodium titanate would form only when $\mathrm{pH}$ is higher than $11^{[17]}$. When $\mathrm{NaOH}$ treated samples are subjected to solution with lower $\mathrm{pH}, \mathrm{Na}$ would be replaced by other cations easily. Calcium titanate is stable in a larger activity-pH domain in relation to the sodium titanate. When $\mathrm{NaOH}$ treated samples are immersed into neutral (or a little acidic) $\mathrm{CaCl}_{2}$ solution, $\mathrm{Na}^{+}$ion could be replaced by $\mathrm{Ca}^{2+}$ to form a calcium titanate hydrogel layer ${ }^{[19]}$. Similar reaction would also happen when $\mathrm{NaOH}$ treated samples are immersed into $\mathrm{MgCl}_{2}$ solution. However, immersion in $\mathrm{MgCl}_{2}$ solution benefits formation of anatase because it is nearly neutral and that less cations are combined into titania hydrogel compared with immersion in $\mathrm{CaCl}_{2}$ solution ${ }^{[19]}$.

\subsection{In vitro apatite forming ability}

Fig.4 shows the SEM images of samples immersed in SBF for $2 \mathrm{~d}$. Typical island-like apatite spherulites are observed on NaTi samples; however their distribution is scattered. Whereas, MgTi sample shows stronger apatite inducing ability and the surface is completely covered by fine apatite spherulites.

$\mathrm{Li}$ et al. proposed that, $-\mathrm{OH}$ groups, such as $\mathrm{Ti}-\mathrm{OH}$, $\mathrm{Si}-\mathrm{OH}$ and $\mathrm{Zr}-\mathrm{OH}$, and negative surface charge were essen- 
tial for apatite formation on materials immersed in $\mathrm{SBF}^{[20]}$. It is also reported that crystal structure played important roles in inducing apatite and crystalline titania layers showed better apatite inducing ability than amorphous ones. Although there is an argument about whether rutile or anatase is effective for apatite formation, it is suggested crystalline titania layers, regardless crystal type and fraction, could induce the same amount of apatite in $\mathrm{SBF}^{[21-23]}$. The

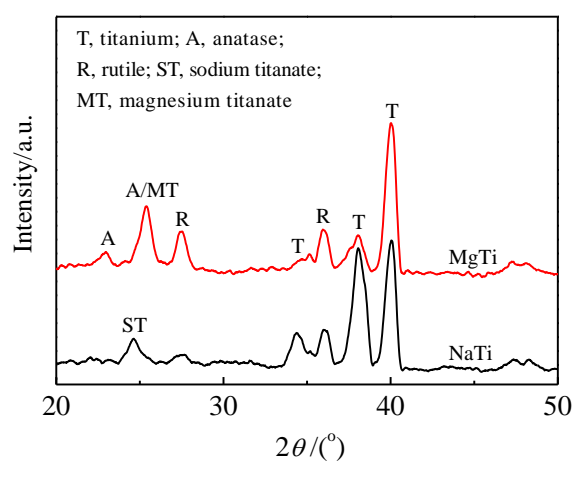

Fig.3 XRD patterns of different specimens

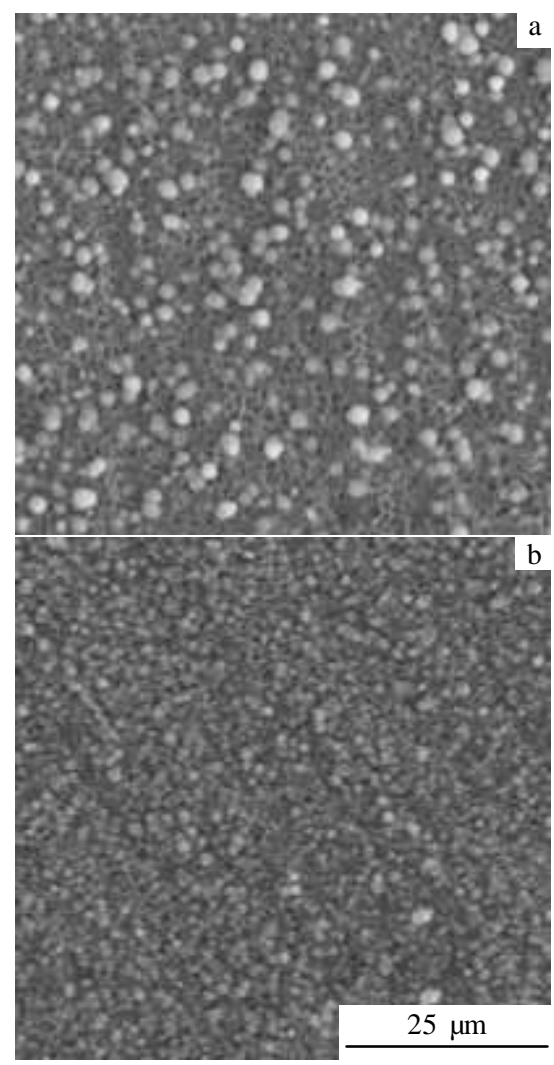

Fig.4 SEM images of specimens immersed in SBF for $2 \mathrm{~d}$ : (a) NaTi and (b) MgTi positive effect of crystalline is confirmed in this study. NaTi samples could be easily hydrated and form Ti-OH in $\mathrm{SBF}$ as sodium would release very fast within short immersion time ${ }^{[24]}$. However, they do not induce apatite as fast as MgTi samples which show relatively stronger signals of crystalline titania in XRD pattern.

\subsection{Protein adsorption}

The amount of albumin adsorbed onto different Ti samples is shown in Fig. 5. Significantly higher amount of protein is adsorbed onto MgTi surface compared with NaTi and UnTi $(p<0.05)$ over the same incubation time. On the other hand, univalent $\mathrm{Na}^{+}$seems not to improve albumin adsorption significantly. Similar results regarding $\mathrm{K}^{+}$have been reported ${ }^{[9]}$.

Electrostatic interactions are believed to play important roles in protein adsorption. However, isoelectric points (IEP) of albumin and $\mathrm{TiO}_{2}$ are 4.7 4.9 and 5.6 6.1, respectively and thus at physiological $\mathrm{pH}$ of 7.0 , both of them possess net negative charges. Therefore, divalent cations, such as $\mathrm{Ca}^{2+}$ and $\mathrm{Mg}^{2+}$, are needed to serve as bridge between titanium implants and protein molecule. Actually, the exclusion of $\mathrm{Ca}$ and $\mathrm{Mg}$ from medium will restrict albumin adsorption onto titanium significantly ${ }^{[25]}$. Protein adsorption onto titanium is limited by the availability of binding sites and therefore introducing $\mathrm{Mg}$ into $\mathrm{Ti}$ can enhance protein adsorption obviously in consideration of that surface topographies of samples are similar in this study.

\subsection{Morphology of attached cells}

Fig. 6 shows that, after $24 \mathrm{~h}$ incubation the attached cells are different in morphology depending on the surface cations. More cells can be observed on MgTi. Besides, cells cultured on MgTi are observed to be spindle-like or polygonal, occupying larger area and displaying more filopo- dia projecting out from the cell compared to cells on NaTi. Lamellipodia with leading and retreating edges, which is the typical feature of migrating cells, are massively observed on MgTi samples, indicating good cell motility.

\subsection{Cell attachment and proliferation}

As shown in Fig.7, the surface composition could significantly affect the initial interaction between cell and material. After $3 \mathrm{~h}$ of culture, cell on MgTi presents the higher attachment compared to NaTi $(p<0.05)$. After $24 \mathrm{~h}$ of culture, cell numbers on samples are approaching the initial value for MgTi and cell proliferation has started. The better initial cell attachments on MgTi samples are succeeded by faster increase in the number of proliferated cells when compared to NaTi samples, as shown in Fig. 8.

The initial attachment of osteoblast cells to implant surface is fundamental for ensuring a successful osseointegration in vivo. Enhanced cell responses to implant material are expected to benefit direct bone-implant contact. Although there are many factors that influence cell-implant interactions, surface chemical composition is 
undoubtedly quite important. Combination of $\mathrm{Mg}$ into $\mathrm{Ti}$ surface by the chemical-heat treatment method enhances protein adsorption greatly as shown in Fig.5. The function of $\mathrm{Mg}$ as bridge cation is apparent, as $\mathrm{MgTi}$ and $\mathrm{NaTi}$ specimens present identical surface topography and roughness.

Early osteoblast responses can be significantly enhanced on $\mathrm{Mg}$ modified titanium by many techniques due to im-proved wettability and increased proteins adsorption and elevated integrins expression ${ }^{[6]}$. However, excessive $\mathrm{Mg}$ incorporation and fast release will depress cell attachment, spreading and proliferation if $\mathrm{Mg}$ is immobilized onto tita-

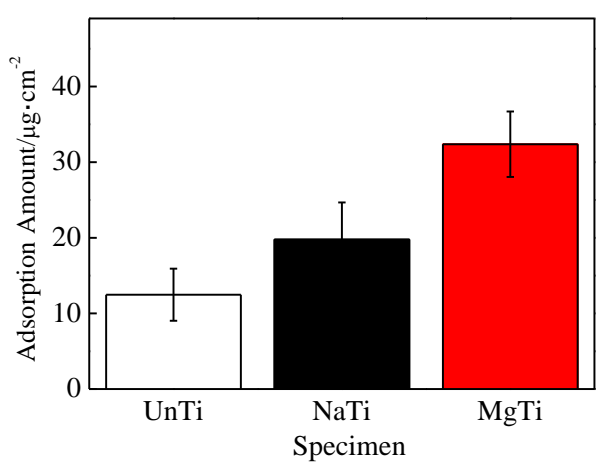

Fig.5 BSA adsorption on different specimens

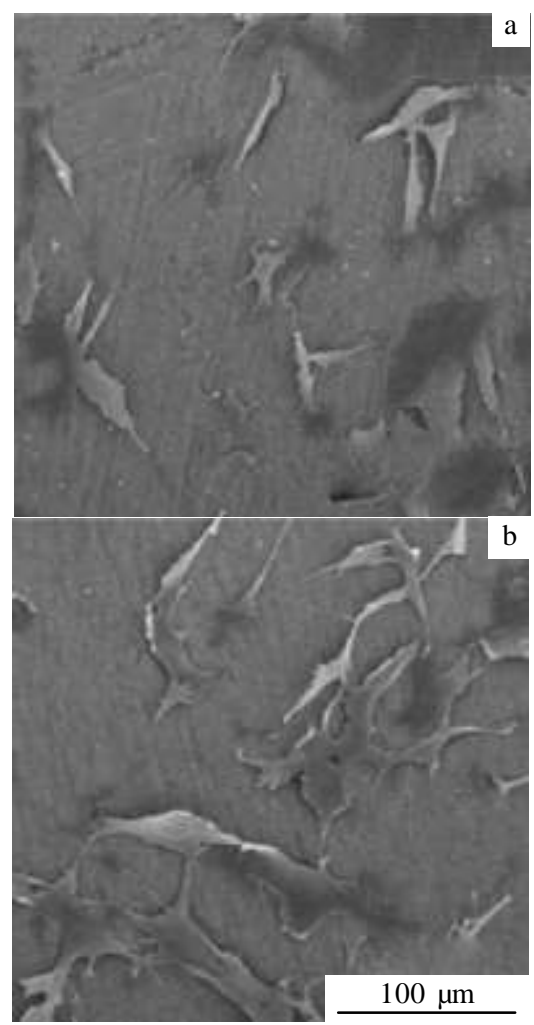

Fig.6 Cell morphologies after seeding 24 h: (a) NaTi and (b) $\mathrm{MgTi}$

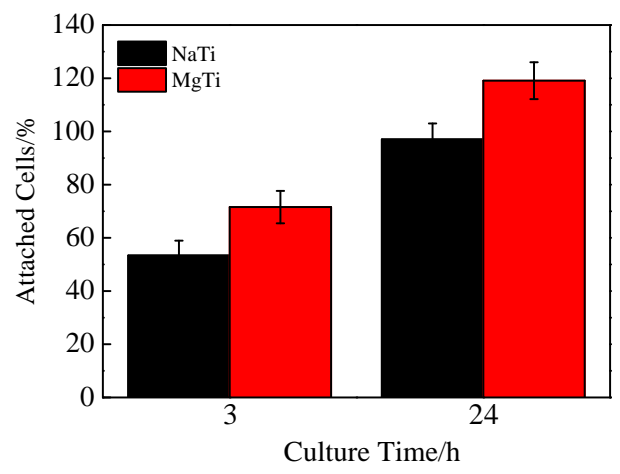

Fig.7 Cell attachment on different specimens

nium surface in a unstable chemical state, such as $\mathrm{Mg}(\mathrm{OH})_{2}{ }^{[8,16]}$. In this study, the heat treatment after ion exchange stabilizes $\mathrm{Mg}$ as magnesium titanate and therefore avoid cell apoptosis as reported ${ }^{[26]}$.

In the last few years, $\mathrm{Mg}$ and its alloys have attracted much attention as biodegradable implant; however, the control over Mg degradation still keeps as challenge and it cannot be used as loading-bearing orthopedic implants ${ }^{[27,28]}$. This study shows that, combining $\mathrm{Mg}$ into $\mathrm{TiO}_{2}$ surface of titanium might be an alternative solution for preparing implants for quick and long-term successful osseointegration.

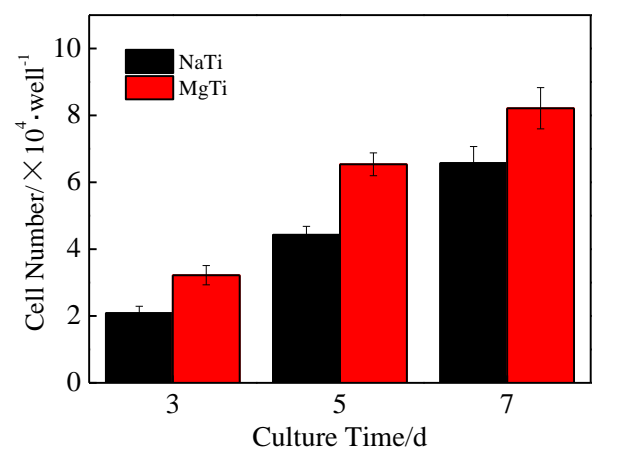

Fig.8 Cell proliferation on different specimens

\section{Conclusions}

1) A titanate network can be synthesized by a simple method based on alkaline treatment followed by an ion-exchange and heat treatment process.

2) This method modifies the chemical composition of titanium surface by $\mathrm{Mg}^{2+}$ incorporation and improves in vitro apatite induction in SBF.

3) This method enhances protein adsorption, prompts osteoblast attachment, spreading and proliferation.

\section{References}


1 Bruni S, Martinesi M, Stio M et al. Acta Biomater[J], 2005, 1(2): 223

2 Frauchiger V M, Schlottig F, Gasser B et al. Biomaterials[J], 2004, 25(4): 593

3 Le Guéhennec L, Soueidan A, Layrolle P et al. Dent Mater[J], 2007, 23(7): 844

4 Kilpadi K L, Chang P L, Bellis S L et al. J Biomed Mater $\operatorname{Res}[\mathrm{J}], 2001,57(2): 258$

5 Arima Y, Iwata H. Biomaterials[J], 2007, 28(20): 3074

6 Zreiqat H, Howlett C R, Zannettino A et al. J Biomed Mater $\operatorname{Res}[\mathrm{J}], 2002,62(2): 175$

7 Zreiqat H, Valenzuela S M, Ben Nissan B et al. Biomaterials [J], 2005, 26(36): 7579

8 Nayab S, Shinawi L, Hobkirk J et al. J Mater Sci-Mater M[J], 2003, 14(11): 991

9 Klinger A, Steinberg D, Kohavi D et al. J Biomed Mater $\operatorname{Res}[\mathrm{J}], 1997,36(3): 387$

10 Shi X L, Wang Q L, Wang F S et al. Mining Science and Technology[J], 2009, 19(2): 220

11 Shi X L, Xu L L, Wang Q L et al. Surf Coat Technol[J], 2010, 205(6): 1730

12 Nakagawa M, Zhang L, Udoh K et al. J Mater Sci: Mater $\operatorname{Med}[\mathrm{J}], 2005,16(11): 985$

13 Nakagawa M, Yamazoe J. J Mater Sci Mater Med[J], 2009, 20(11): 2295

14 Shi X, Nakagawa M, Kawachi G et al. J Mater Sci Mater
$\operatorname{Med}[\mathrm{J}], 2012,23(5): 1281$

15 Nayab S N, Jones F H, Olsen I et al. Biomaterials[J], 2005, 26(23): 4717

16 Shi X, Tsuru K, Xu L et al. Appl Surf Sci[J], 2013, 270: 445

17 de Andrade M C, Filgueiras M R T, Ogasawara T et al. J Biomed Mater Res[J], 1999, 46(4): 441

18 Kokubo T, Takadama H. Biomaterials[J], 2006, 27(15): 2907

19 Kizuki T, Takadama H, Matsushita T et al. Acta Biomater [J], 2010, 6(7): 2836

20 Li P J, Ohtsuki C, Kokubo T et al. J Biomed Mater Res[J], 1994, 28(1): 7

21 Cui X, Kim H M, Kawashita M et al. Dent Mater[J], 2009, 25(1): 80

22 Uchida M, Kim H M, Kokubo T et al. J Biomed Mater Res $A[\mathrm{~J}], 2003,64(1): 164$

23 Wu J M, Hayakawa S, Tsuru K et al. J Am Ceram Soc[J], 2004, 87(9): 1635

24 Takadama H, Kim H M, Kokubo T et al. J Biomed Mater $\operatorname{Res}[\mathrm{J}], 2001,55(2): 185$

25 Jansson E, Tengvall P. Colloid Surface B[J], 2004, 35(1): 45

26 Ren N, Li J H, Qiu J C et al. Small[J], 2014, 10(15): 3169

27 Bauer M, Schilling T, Weidling M et al. J Mater Sci-Mater $M[\mathrm{~J}], 2014,25(3): 909$

28 Bobe K, Willbold E, Morgenthal I et al. Acta Biomater [J], 2013, 9(10): 8611

\section{纯钛表面镁离子改性后磷灰石沉积、蛋白质吸附及成骨细胞初期反应的研究}

徐玲利, 史兴岭, 欧阳春, 刘 文

(江苏科技大学, 江苏 镇江 212003)

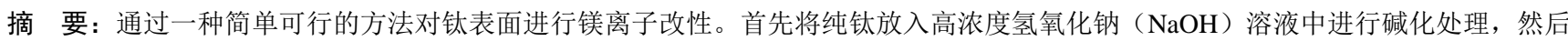
再转移至稀氯化镁 $\left(\mathrm{MgCl}_{2}\right)$ 溶液中进行离子交换, 最后进行热处理, 在纯钛试样表面形成了含有钛酸镁成分的 $3 \mathrm{D}$ 纳米网状结构。对 试样的表面形貌、粗糙度和化学组成进行了分析; 考察了试样在模拟人工体液中诱导羟基磷灰石沉积的能力; 以牛血清白蛋白为模型, 研究了表面改性对纯钛试样蛋白吸附能力的影响; 评价了 MC3T3-E1 成骨细胞在试样表面的附着、铺展和增殖。结果表明, 与钠（Na） 离子改性相比, 镁离子改性加快了羟基磷灰石在试样表面的沉积, 并明显促进了蛋白吸附。此外, 镁离子改性促进了成骨细胞附着、 铺展及随后的增殖。

关键词: 钛; 骨传导性; 镁; 磷灰石; 蛋白质; 成骨细胞

作者简介：徐玲利，女, 1982 年生, 硕士, 江苏科技大学材料科学与工程学院, 江苏 镇江 212003, 电话: 0511-84401184, E-mail: xulingli311@ hotmail.com 